\title{
Impact of HR Practices on Employee Turnover and Job Satisfaction: Evidence from Pakistani Universities
}

\author{
Shakeel Khan ${ }^{a}$, Muhammad Hashim Khan ${ }^{b}$, Ali Muhammad Mohmand ${ }^{c}$, Syeda Misbah ${ }^{d}$ \\ ${ }^{a}$ Lecturer Institute of Management Studies, University of Peshawar, Pakistan \\ Email: shakeel.ims@uop.edu.pk \\ ${ }^{\mathrm{b}}$ Lecturer Institute of Management Studies, University of Peshawar, Pakistan \\ Email: hashim@uop.edu.pk \\ ${ }^{c}$ Assistant Professor Institute of Management Studies University of Peshawar, Pakistan \\ Email: alimohmand@uop.edu.pk \\ ${ }^{\mathrm{d}}$ MBA (Graduated) Institute of Management Studies University of Peshawar, Pakistan \\ Email: syedamisbah@hotmail.com
}

\begin{tabular}{l}
\hline ARTICLE DETAILS \\
\hline History: \\
Accepted 21 July 2020 \\
Available Online 30 September \\
2020
\end{tabular}

\section{Keywords:}

HR Practices, Job Satisfaction,

Turnover, Performance

Appraisal, Employee

Participation

\section{JEL Classification:}

O15, J28, I25

DOI: $10.47067 /$ reads.v6i3.250

\section{ABSTRACT}

This research examines the impact of pertinent $H R$ practices/policies upon a person's job contentment and turnover in higher educational institutes. A special context of universities of KP have been chosen where numerous employees have developed job dissatisfaction and increased turnover because of deteriorating security conditions including but not limited to terrorism attacks, civil unrest, widespread diseases and conducive working environment. This has ultimately compelled them to leave their jobs and flee to other cities such as Islamabad and Karachi. More specifically, three $H R$ policies i.e. employee participation, training and performance appraisal are analyzed to affect job satisfaction and turnover. A quantitative survey was conducted to assess job outcomes of University teachers in multiple cities especially where living conditions have deteriorated in the recent past. Respondents were segregated on the basis of age, income per month, designation and gender basis. Frequency analysis and Mean Average Scores are reported for each construct. The regression results suggest a positive significant relation of employee participation and performance appraisal with that of job satisfaction while a significant negative relation is found with turnover ratio. The study concludes that universities should focus on implementing $H R$ policies and practices effectively in workplace which will help retain employees and keep them motivated. This can be one of the many effective strategies to retain workforce and discourage brain-drain out of the country. The study ends with acknowledging limitations and offering future research directions.

(C) 2020 The authors. Published by SPCRD Global Publishing. This is an open access article under the Creative Commons Attribution- 


\section{Introduction}

Today's organizations are generally engaged in seeking more effective ways to increase productivity and to keep abreast with the enhanced competition to uphold its unique identity in the market. To achieve this very purpose they try to practically imply various tools and techniques including but not limited to accounting, financing and human resource decisions. Among all those techniques and practices, the Human Resource (HR) Practices hold a supreme position that can play a vital role in the overall effectiveness and efficiency of an organization.

The association between HR practices and Job satisfaction is researched extensively in contemporary management world. Following other researchers in Europe and America, Belzen (2009) examines this association in a Dutch sample. Another study put forward by Brown and Hewood (2005) assert that employees' productivity can also be increased rapidly by providing them better opportunities for their career development. The literature also shows the importance of supervisor in organization in some emerging economies (Ma et al., 2016; Shaffer et al., 1999) Furthermore, Selmer (2001) state that the role of a supervisor is like a bridge that links the workers with the upper management of an organization.

The overall progress of the organization is one way or the other, influenced by prevalent HR practices (Stavrou, 2005). The key to success for an organization is to implement or adopt the ways and means how to satisfy the current employees. Existing research offers theoretical foundations and frameworks which can be the bases for bringing more holistic solution to a local personnel problem. (Arumugam and Mojtahedzadeh, 2011). The personal satisfaction of the employees will lead to a strong commitment towards organization and eventually will lead to lesser levels of turnover.

The concept of remuneration is vital because according to Aswathappa, (2008) it constrain the employees to stick to the job that yields more organizational productivity and less turn over. Remuneration is also another foundation building element that includes all the monetary and nonmonetary incentives a worker receives in return of catering the services to an organization (Gary, 2008, p. 390). It may be concluded that the organizational endmost success is more or less dependent on the HR practices in use by the firm. The Human resource management if done effectively can ultimately lead to higher employee contentment and reduced turnover.

The focal point of research is to examine the impact of various HR practices and policies on employee turnover and to determine and suggest an appropriate mix of strategies that can be put into practice in order to reduce turnover in organizations. Job satisfaction is a vivid concept and is the foundation of any organization's success and prosperity. An organization flourishes only because of its employees. Therefore keeping employees satisfied is of prime importance to the success of organisations.

The proposed research inspects the impact of unmatchable complementary HR practices that act as basis to employee's satisfaction and lead to a progressive organizational output. To put the concept into practice the study takes into account the teacher's satisfaction in the context of renowned universities in Khyber Pakhtunkhwa Pakistan. Narrowing the discussion into specific outlines, the research strives to achieve the following objectives.

- To find out an association between the different HR practices, policies and work outcomes such as Job satisfaction and turnover ratios in higher education institutions (HEI's) of Pakistan. 


\section{Review of Economics and Development Studies, Vol. 6 (3) 2020, 607-624}

- To examine as to what extent the levels of contentment and turnover ratios are determined by underlying factors in the human resource policies of training, employee participation and performance appraisal system.

- To draw suggestive measures to accomplish an enhanced levels of job satisfaction and reduced turnover ratio amongst university employees in an environment of chaos and conflict, such as the one in prevalent KP Pakistan.

\section{Review of Literature and Hypothesis}

Job satisfaction is a crucial element in general organizational behaviour and its impact on the employee's overall performance is unavoidable. There are many contributors which plays their part actively to achieve the target including employee contribution, job specification, reimbursement, career management system, performance appraisements and selection criterion. A comprehensive research model is therefore formulated which encapsulates the general workforce practices and influence of job satisfaction on the productivity and outcome of Malaysian industries in particular (Arumugam \& Mojtahedzadeh, 2011). Job satisfaction has also been extensively used as a mediating variable in promoting HR practices (Kundu \& Gahlawat, 2015).

An investigation conducted by Olusegun, (2013) in South West Nigeria on the university employees revealed that there is an obvious distinctiveness in the linear combination effect of employee satisfaction and turnover intents. A research study carried out by Khan et al. (2012) took university instructors and considered the three distinctive sectors of Pakistan including the government, semi government and private sectors, revealed a gender bifurcated results. It was observed that female instructors are more likely to get influenced by the HR practices, whereas male teachers are more interested in their work and usually get satisfaction out of it.

Another study done by Huselid, (1995) suggested on the bases of sample gathered from around 1000 firms, exhibiting the significance of economical and statistical impression over transitional employee's outgrowth and the corporate financial growth in both short and long run respectively. The investigation regarding HR contribution reveals that the employee's approach and overall conduct is the outcome of HR practices and the way workers acknowledge the administration (Nishi, lepak \& Schneider, 2008). A constructive association can be observed in between salary strategies and work enhancement with job satisfaction/contentment, worker's devotion with job improvement strategies and strategies related with work balancing (Roberto \& Jaoquin, 2007).

The research also revealed the inverse relationship between worker's commitment and planned turnover. The influence of HRM practices with respect to HR outcomes targeting the Government banks operating in Sri Lanka was investigated by Rathanweera (2010). The collection of data was done with the use of structured questionnaires in which the worker's approaches towards HR practices was analyzed. Sample based on 209 workers was gathered from various departments of two Sri Lankan Government banks. The conclusion reflected that HR practices are the foreseeing instruments of worker's contentment, commitment and withholding Rathanweera (2010).

Belzen, (2009) also studied the relationship between job satisfaction and HR practices , according to him the improved HR practices powerfully influence the worker's built in relevant job contentment. The research indicates that the organizations with higher and more advanced HR practices finally yields to greater job satisfaction. An investigation done by Hussain and Rehman (2013) suggested that the association between HR practices and job security, training and inductions are strongly participating in the retention process and influences employees to retain their services with 


\section{Review of Economics and Development Studies, Vol. 6 (3) 2020, 607-624}

the organization. According to Mahmud and Idrish, (2011) the job related imbursements and in depth analysis of work are strong indicators predicting the intention of an employee to quit.

Another study carried out in Bangladesh by Absar, Azim, Balasundaram (2010) revealed a significant relationship between improved HR strategies and the number of satisfied and dedicated employees. A study done by Mumtaz, Aslam and Ahmad, (2011) to find out the influence of HR practices on job satisfaction of University instructors. The findings revealed that the mentioned set of HR practices did not influence the teacher's contentment which thus indicates that the other factors are still to get unveiled impacting teacher's satisfaction in general.

Success of the firm is highly motivated by the effective implementation of HR practices (Stavrou, 2005). The concept proposed by Locke in 1976 was used by Haque and Taher, (2000) they proposed that job satisfaction is an optimistic emotional feeling which can be attained from a comprehensive interpretation of the person's work. The major determinants of job satisfaction includes worker's necessities and wants, social affiliations, management practices, job structure and design, reimbursement, long term chances (Moorhead and Griffin, 2001).

Huselid, Jackson and Schular (1995) proposed in their studies that high-progressive work practices yields to lower turnover rate. Turnover is generally regarded as the number of employees leaving the job. HRM practices and policies also increase appraisements, for instance provision of financial incentives and opportunities of formal trainings enhances organizational output (Brown \& Hewood, 2005). Mobley (1978) suggested that the intentions can fluctuate from the influence of an affiliation between job satisfaction and turnover. Majority of investigators accepts the fact that turnover intent is the last step of intentional turnover Mahmud and Idrish (2011).

\subsection{Theory and Conceptual Framework}

While there are several theories relating Job satisfaction and HR practices, we chose Human Capital theory and Efficiency Wage theory. Human capital theory (Blaug, 1976) suggests that organizations invest in human capital to retain talented employees. They develop internal resources to justify employee skills for future productivity. Employments opportunities can be internalized or externalized accordingly based on the HR practices operating to achieve better productivity. Therefore important practices such as training, and employee participation may affect job satisfaction and turnover ratios.

In line with this, Efficiency wage theory (Akerlof, 1984) suggests that turnover ratio may be strongly related to pay practices and performance appraisal system in order to maintain efficiency in organizations. Based on the literature, our research framework is shown in figure 1. The model depicts a relationship between HRM practices, turnover and job satisfaction. The HRM practices acts as an independent variable (IDV) whereas turnover and job satisfaction reflects dependency on HRM practices. Hence they are dependent variables (DV). 
Personnel Practices (Ind. Variables)

Dependent Variables

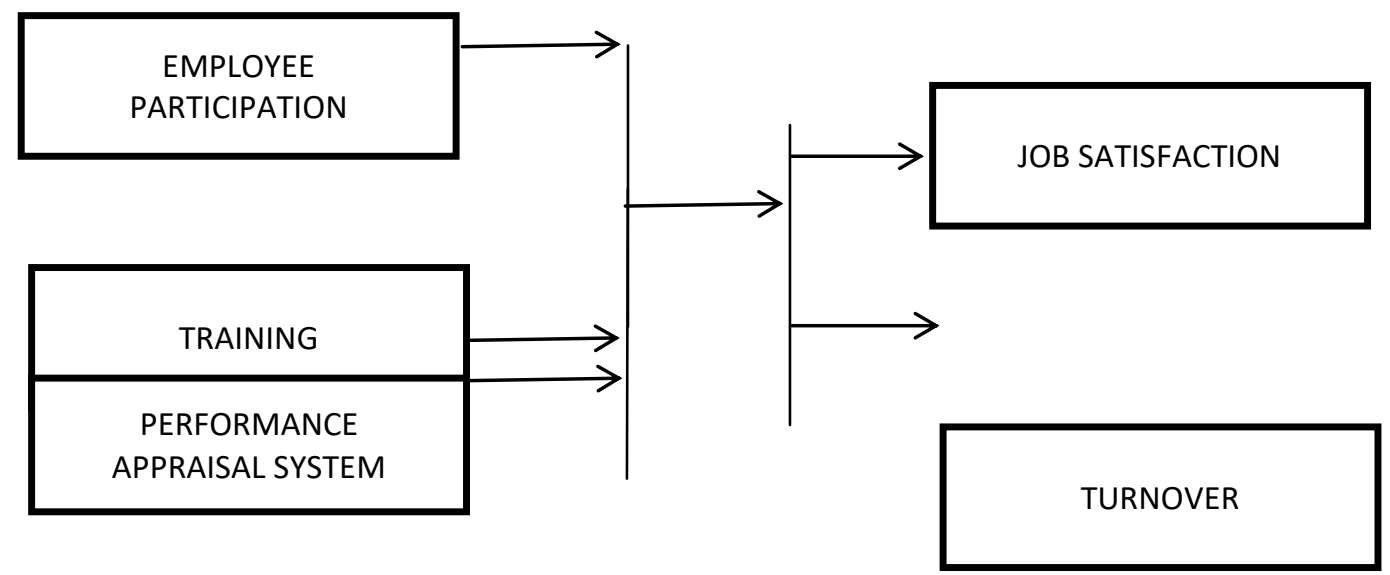

Figure 1: An association of HRM practices, Job satisfaction and Turnover

The variables that are considered in this research include HRM practices (performance appraisal system, training and employee participation), job satisfaction and turnover.

\subsection{Hypothesis}

On the bases of the above literature the following hypothesis are developed for investigation.

$\mathbf{H}_{\mathbf{1}}$ : There will be a compelling association between employee participation and turnover.

$\mathbf{H}_{\mathbf{2}}$ : There will be a compelling association between training and turnover.

$\mathbf{H}_{3}$ : There will be a significant association between Performance appraisal system and turnover.

$\mathbf{H}_{4}$ : There will be a compelling relationship between employee participation and job satisfaction.

$\mathbf{H}_{5}$ : There will be a significant relationship between training and job satisfaction.

$\mathbf{H}_{6}$ : There will be a compelling relationship between performance appraisal system and job satisfaction.

\section{Research Methodology}

\subsection{Sample and Data Collection}

The research is based on taking into account all major sector universities operating in the province of KP. Hence all universities are taken as the universe of study. There were 6 participant universities namely Sarhad University, Iqra National University (INU), Peshawar University, Malakand University, Kohat University and Bannu University. These universities were selected to constitute a relatively representative sample of cities where there were increased incidences of terrorism and unrest in the recent past.

The sample consisted of 125 teachers of the above mentioned reputable institutions. This sample size was achieved with the help of physically administered survey in each participating university. The process of data collection was performed with the support of colleagues in sister universities.

\subsection{Statistical Model and Conceptual Framework}

The representation is on the basis of ratios and percentages because the variables used were of 


\section{Review of Economics and Development Studies, Vol. 6 (3) 2020, 607-624}

subjective nature. The statistical package for Social Sciences (SPSS) has been used for interpretation of the collected data. For establishment of relativity in between defined variables which include employee participation, performance appraisal system, job satisfaction, training and turnover, the statistical techniques of correlation and regression are used. Regression analysis incorporates methods for modelling and analysing different dependent and independent variables. It can mathematically be expressed as

$$
\mathrm{Y}=\mathrm{B}_{\mathrm{o}}+\mathrm{B}_{1} \mathrm{X}+\ldots \ldots \ldots \ldots \ldots+\mathrm{e}
$$

The equation showing relationship between job satisfaction, employee participation, training and performance appraisal.

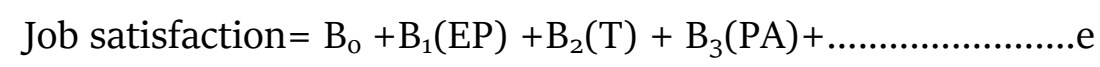

Where, EP represents Employee Participation

$\mathrm{T}$ represents training PA represents Performance Appraisal

E represents the error term

And $\mathrm{B}_{1}, \mathrm{~B}_{2}$ and $\mathrm{B}_{3}$ represents the coefficients of regression.

The equation defining the relationship between turnover, employee participation, training and performance appraisal.

$$
\text { Turnover }=\mathrm{Bo}+\mathrm{B}_{1}(\mathrm{EP})+\mathrm{B}_{2}(\mathrm{~T})+\mathrm{B}_{3}(\mathrm{PA})+\ldots \ldots \ldots \ldots \ldots \ldots \ldots . . . \mathrm{e}
$$

EP represents employee participation

$\mathrm{T}$ represents training

PA represents performance appraisal

E represents the error term

And $\mathrm{B}_{1}, \mathrm{~B}_{2}$ and $\mathrm{B}_{3}$ represents the coefficients of regression

\subsection{Constructs and Measures}

All of related constructs along with their measuring techniques are discussed below:

\subsubsection{HR practices:}

The HRM practices reflect a positive relationship between organizational innovation, product innovation, process innovation and administrative innovation. HRM practices were measured using 5items Likert scale ranging from 1 to 5 and representing two extreme ends of 'strongly agree' and 'strongly disagree' respectively.

\subsubsection{Job satisfaction:}

Job satisfaction is an integral part of HR practices as it influences and motivates employee to contribute to the fullest in the productivity and effectiveness of an organization. Job satisfaction was measured on 6-item scale formulated by Agho, Price and Mueller (1992). Each individual component was measured on 5 -item Likert scale ranging from 1 (Strongly agree) to 5 (Strongly disagree). 


\subsubsection{Employee turnover:}

The term refers to the ratio of workers left and replaced by the new workers. This construct has been measured by a 3-items scale invented by Vigoda in 1990. The scale ranging from 1 (Strongly disagree) to 5 (Strongly agree) has been used.

\section{Analysis and Results}

4.1 Correlation analysis between HRM practices, job satisfaction and turnover

Table 1:- Pearson correlation with respect to age, designation, job experience and income

\begin{tabular}{|l|l|l|l|l|l|}
\hline & Gender. & Age. & Design. & Experience. & Income. \\
\hline Gender. & 1. & & & & \\
\hline Age. & 0.052 & 1 & & & \\
\hline Design. & 0.044 & $0.495^{* *}$ & 1. & & \\
\hline Experience. & 0.003 & $0.667^{* *}$ & $0.443^{* *}$ & 1. & \\
\hline Income. & 0.056 & $0.557^{* *}$ & $0.548^{* *}$ & $0.396^{* *}$ & 1. \\
\hline
\end{tabular}

Table 2:- Pearson correlation with respect to dependent and independent variables

\begin{tabular}{|l|l|l|l|l|l|}
\hline & $\begin{array}{l}\text { Employee } \\
\text { Contribution }\end{array}$ & $\begin{array}{l}\text { Training\& } \\
\text { Induction }\end{array}$ & $\begin{array}{l}\text { Performance } \\
\text { Appraisal System }\end{array}$ & $\begin{array}{l}\text { Job } \\
\text { Satisfaction }\end{array}$ & $\begin{array}{l}\text { Employee } \\
\text { Turnover }\end{array}$ \\
\hline $\begin{array}{l}\text { Employee } \\
\text { Contribution }\end{array}$ & 1 & & & & \\
$\begin{array}{l}\text { Training\& } \\
\text { Induction }\end{array}$ & $0.496^{* *}$ & 1 & & & \\
\hline Per. app system & $0.604^{* *}$ & $0.601^{* *}$ & 1 & & \\
\hline Work satisfaction & $0.713^{* *}$ & $0.554^{* *}$ & $0.679^{* *}$ & 1 & \\
\hline Emp. turnover & $-0.422^{* *}$ & $-0.218^{*}$ & $-0.412^{* *}$ & $-0.526^{* *}$ & 1 \\
\hline
\end{tabular}

* Significance at 0.05 level (two-tailed)

**Significance at O.O1 level (two-tailed)

Pearson Coefficient is a statistical tool for measuring the linear correlation between two variables $X$ and $Y$, giving a value between +1 and -1 inclusive, where 1 is total positive correlation, $o$ is no correlation, and -1 is total negative correlation. Table 1 and 2 demonstrates the Pearson Correlation Coefficient for the researched variables and is utilized to compare the mean in accordance with the designated demographic variables and all the other key factors with the confidence interval of $(p<0.01)$. The assumptions made about the variables correlation were stand significant having value less than 0.01 except one counted as $-0.218^{*}$. The negative sign is an indication of diminished turnover if the worker is provided with significant appraisal system, is cooperative, well equipped with his skills and is happy with the working environment. In the research paper the stark on the figure symbolizes the significance of correlation w.r.t the achieved confidence interval which in our case is $(\mathrm{P}<0.05)$. 


\subsection{Inspecting reliability:}

To understanding the reliability factor of this investigation, we performed reliability analysis technique using SPSS. Table. 3 present the results of each dependent/independent variable.

\section{Table 3: Results of reliability analysis of variables}

\begin{tabular}{|l|l|l|}
\hline Variable & Cronbach's alpha & Remarks \\
\hline Worker's Contribution & 0.794 & Reliable \\
\hline Training \& Induction & 0.839 & Reliable \\
\hline $\begin{array}{l}\text { Performance Appraisal } \\
\text { System }\end{array}$ & 0.822 & Reliable \\
\hline Job Satisfaction & 0.811 & Reliable \\
\hline Turnover & 0.854 & Reliable \\
\hline
\end{tabular}

The interpretation considers five distinguished variables including Employee contribution, Training\& Induction, Performance appraisal criteria, Job satisfaction and employee's turnover in accordance to a cut-off value of Cronbach's alpha of 0.7 as suggested by Week (2000), and Cronbach (1951).

From above depicted table it is clear that employee participation is interpreted as the least reliable variable by possessing the Cronbach's alpha of 0.794 . Whereas all the other consecutive variables including training, performance appraisal system, job satisfaction and employee turnover possess reliability in the order of $0.839,0.822,0.811$ and 0.854 respectively. Thus all variables qualify in the acceptable range of Cronbach's alpha which makes the authenticity of data quite reliable and assures provision of exhibitive and helpful framework.

\subsection{Distributing respondents with respect to employee contribution, training, performance} appraisal, job satisfaction and turnover

The respondents are distributed with respect to the factors including employee contribution, training, performance appraisal system, job contentment/satisfaction and turnover. All of them are studied individually along with the tabular analysis to get a clearer picture.

Table 4: distribution of respondents with respect to employee contribution

\begin{tabular}{|c|c|c|c|c|c|c|c|}
\hline \multirow[t]{2}{*}{ S.No } & \multirow[t]{2}{*}{ Item } & \multicolumn{5}{|c|}{ Employee Perception } & \multirow[t]{2}{*}{ MAS } \\
\hline & & 1. & 2. & 3. & 4. & 5. & \\
\hline 1 & $\begin{array}{l}\text { You are a good contributor in your } \\
\text { institution's affairs }\end{array}$ & $\begin{array}{l}6 . \\
(4 \cdot 9)\end{array}$ & $\begin{array}{l}5 \cdot \\
(4 \cdot 1)\end{array}$ & $\begin{array}{l}17 . \\
(13 \cdot 7)\end{array}$ & $\begin{array}{l}66 . \\
(52.9)\end{array}$ & $\begin{array}{l}31 . \\
(24 \cdot 9 \\
)\end{array}$ & 3.8881 \\
\hline 2 & $\begin{array}{l}\text { You are zealous regarding } \\
\text { employment at your present } \\
\text { institution. }\end{array}$ & $\begin{array}{l}1 \\
(0.8)\end{array}$ & $\begin{array}{l}10 \\
(8.0)\end{array}$ & $\begin{array}{l}28 \\
(22.4 \\
)\end{array}$ & $\begin{array}{l}62 \\
(49 \cdot 6)\end{array}$ & $\begin{array}{l}24 \\
(19.2)\end{array}$ & 3.7840 \\
\hline 3 & $\begin{array}{l}\text { You show concern in making } \\
\text { decisions/policies } \\
\text { institution. }\end{array}$ & $\begin{array}{l}26 \\
(20.8 \\
)\end{array}$ & $\begin{array}{l}49 \\
(39.2 \\
)\end{array}$ & $\begin{array}{l}18 \\
(14 \cdot 4)\end{array}$ & $\begin{array}{l}25 \\
(20.0)\end{array}$ & $\begin{array}{l}7 \\
(5.6)\end{array}$ & 2.5040 \\
\hline 4 & $\begin{array}{l}\text { Your institution provides you an } \\
\text { opportunity to contribute in the } \\
\text { formulation of academic policy. }\end{array}$ & $\begin{array}{l}30 \\
(24 \cdot 0 \\
)\end{array}$ & $\begin{array}{l}34 \\
(27.2 \\
)\end{array}$ & $\begin{array}{l}17 \\
(13.6)\end{array}$ & $\begin{array}{l}38 \\
(30.4)\end{array}$ & $\begin{array}{l}6 \\
(4.8)\end{array}$ & 2.6480 \\
\hline
\end{tabular}


Review of Economics and Development Studies, Vol. 6 (3) 2020, 607-624

\begin{tabular}{|l|l|l|l|l|l|l|l|}
\hline 5 & $\begin{array}{l}\text { Your University gives you an } \\
\text { opportunity to practice leadership } \\
\text { skills. }\end{array}$ & $\begin{array}{l}27 \\
(21.6)\end{array}$ & $\begin{array}{l}35 \\
(28.0 \\
)\end{array}$ & $\begin{array}{l}29 \\
(23.2 \\
)\end{array}$ & $\begin{array}{l}23 \\
(18.4)\end{array}$ & $\begin{array}{l}11 \\
(8.8)\end{array}$ & 2.6480 \\
\hline 6 & $\begin{array}{l}\text { Your university work place supports } \\
\text { team oriented working practices. }\end{array}$ & $\begin{array}{l}11 \\
(8.8)\end{array}$ & $\begin{array}{l}18 \\
(14.4)\end{array}$ & $\begin{array}{l}25 \\
(20.0 \\
)\end{array}$ & $\begin{array}{l}56 \\
(44.8)\end{array}$ & $\begin{array}{l}15 \\
(12.0)\end{array}$ & 3.3680 \\
\hline 7 & $\begin{array}{l}\text { Your institution welcomes creative } \\
\text { feedback and suggestions of } \\
\text { instructors. }\end{array}$ & $\begin{array}{l}27 \\
(21.6)\end{array}$ & $\begin{array}{l}34 \\
(27.2 \\
)\end{array}$ & $\begin{array}{l}24 \\
(19.2)\end{array}$ & $\begin{array}{l}31 \\
(24.8)\end{array}$ & $\begin{array}{l}9 \\
(7.2)\end{array}$ & 2.6880 \\
\hline & Aggregate Mean & & & & & & 3.0755 \\
\hline
\end{tabular}

$1=$ strongly Disagree, $2=$ Disagree, $3=$ neutral, $4=$ Agree, $5=$ strongly Agree; MAS = mean average score

Table 4 shows that majority of the respondents lie in the $4^{\text {th }}$ part of the Likert Scale. The result directs that the respondents from the universities of KP are in favour of employee contribution. The perception reflects a positive behaviour of employees which can finally be seen in the self-fulfilment and turnover. These findings are based on MAS (mean average scores) calculated by taking statistical averages of all items involved.

On the other hand a substantial number of respondents with neutral perception can also be seen along with some having negative perceptions. The evaluation of items 2, 6 and 1 reflects the approval of the relevant perception as the MAS for that particular category is greater than 3 . However items $3,4,5$, and 7 with MAS $<3$ reflects a negative perception indicating a disagreement of employees about positive employee's participation. The greatest MAS (3.8881) have been observed for item stating respondents' contribution towards their job which results in greater satisfaction and diminished employee turnover.

Item 2 on the other hand depicts MAS (3.7840) which enlightens the zeal of employees towards their workplace resulting in greater satisfaction and fewer intentions to leave the job. Followed by the category 6 with MAS (3.3680) which demonstrates the agreeableness of respondents towards their work and working environment in general. MAS (2.6880), MAS (2.5040), MAS (2.6480) highlights the idea of innovative feedback acceptance, involvement in strategic decision making, chance to show leadership qualities and involvement in general policy formulation. All of them are responsible for noticeable employee satisfaction and turnover. Items 7, 3, 4 and 5 however represents negative recording of perception.

The overall MAS value (3.075) though represents a positive feedback given by respondents in accordance with their participation, satisfaction and turnover. In addition, generally it is observed that greater empowerment, and involvement usually acts as motivational factors. A person will show greater enthusiasm towards work or will act more participative if he will get a chance to think good/bad for the organizations and a free hand to make decisions accordingly.

\subsubsection{With respect to training:}

Training plays a crucial part in employee's growth and satisfaction as it opens uncountable doors of success and polish work with unmatchable skills. Table 5 illustrates the distribution criteria w.r.t training. 
Review of Economics and Development Studies, Vol. 6 (3) 2020, 6o7-624

Table 5: Distribution of respondents with respect to training

\begin{tabular}{|c|c|c|c|c|c|c|c|}
\hline \multirow[t]{2}{*}{ S.No } & \multirow[t]{2}{*}{ Item } & \multicolumn{5}{|c|}{ Employee Perception } & \multirow[t]{2}{*}{ MAS } \\
\hline & & 1. & 2. & 3. & 4. & 5. & \\
\hline 1 & $\begin{array}{l}\text { You can avail before- } \\
\text { service assistance at your } \\
\text { University }\end{array}$ & $\begin{array}{l}43 \\
(34 \cdot 4)\end{array}$ & $\begin{array}{l}41 \\
(32.8)\end{array}$ & $\begin{array}{l}18 \\
(14.4)\end{array}$ & $\begin{array}{l}17 \\
(13.6)\end{array}$ & $\begin{array}{l}6 \\
(4.8)\end{array}$ & 2.2160 \\
\hline 2 & $\begin{array}{l}\text { Lecturers can benefit } \\
\text { from innovative training } \\
\text { at your University }\end{array}$ & $\begin{array}{l}38 \\
(30.4)\end{array}$ & $\begin{array}{l}46 \\
(36.8)\end{array}$ & $\begin{array}{l}16 \\
(12.8)\end{array}$ & $\begin{array}{l}16 \\
(12.8)\end{array}$ & $\begin{array}{l}9 \\
(7.2)\end{array}$ & 2.2960 \\
\hline 3 & $\begin{array}{lrr}\text { Fresh } & \text { Lecturers } & \text { can } \\
\text { benefit } & \text { from } & \text { on-job } \\
\text { training } & \text { at } & \text { your } \\
\text { University } & & \\
\end{array}$ & $\begin{array}{l}26 \\
(20.8)\end{array}$ & $\begin{array}{l}39 \\
(31.2)\end{array}$ & $\begin{array}{l}19 \\
(15.2)\end{array}$ & $\begin{array}{l}25 \\
(20.0)\end{array}$ & $\begin{array}{l}16 \\
(12.8)\end{array}$ & 2.7280 \\
\hline 4 & $\begin{array}{l}\text { Your University gives } \\
\text { Inter-personal } \\
\text { improvement assistance } \\
\text { for instructors. }\end{array}$ & $\begin{array}{l}36 \\
(28.8)\end{array}$ & $\begin{array}{l}52 \\
(41.6)\end{array}$ & $\begin{array}{l}16 \\
(12.8)\end{array}$ & $\begin{array}{l}19 \\
(15.2)\end{array}$ & $\begin{array}{l}2 \\
(1.6)\end{array}$ & 2.1920 \\
\hline 5 & $\begin{array}{l}\text { Your University provides } \\
\text { imperative guidance to } \\
\text { the Instructors. }\end{array}$ & $\begin{array}{l}41 \\
(32.8)\end{array}$ & $\begin{array}{l}50 \\
(40.0)\end{array}$ & $\begin{array}{l}12 \\
(9.6)\end{array}$ & $\begin{array}{l}19 \\
(15.2)\end{array}$ & $\begin{array}{l}3 \\
(2.4)\end{array}$ & 2.1440 \\
\hline & Aggregate Mean & & & & & & 2.3152 \\
\hline
\end{tabular}

$1=$ strongly Disagree, $2=$ Disagree, $3=$ neutral, $4=$ Agree, $5=$ strongly Agree; MAS $=$ mean average score

The findings inferred in table 5 indicate respondents' perception w.r.t Training whereby most of the asked queries regarding Training lie in the second category of Likert Scale. The conclusions depicts that the teachers from the selected Universities are against the process of giving training by their relevant organizations. This negative perception will ultimately affect employees overall satisfaction and turnover. In the same way, there are employees with positive perception towards the concept too while teachers with neutral perception may also be seen. If we analyze in detail, it is obvious that item 4 having maximum percentage of $41.6 \%$ lies within second category of Likert scale representing majority of teachers taking up the inter-personal guidance at their relevant universities. Item 5 again with 40\% reveals the absence of strategic training at their working place. On the other hand items 2, 3 and 4 indicates negative perception regarding pre-service, innovative and on-job training. The aggregate MAS reflect negativity in perception regarding training and guidance manuals of the educational institutions. The negative perception thus reflects disappointment in teacher's behavior with regard to provision of training methodologies. In short the lack of training opportunities will raise the feeling of discouragement and demotivation amongst employees. They will see no ways via which they can enhance their current skills. The final impact can be seen in their job satisfaction feedback which for sure will reflect this lacking and increased employee turnover.

\subsubsection{With respect to performance appraisal system}

It is associated with human nature that he/she must be influenced by the encouragement and compensation they receive in return of services they offer. The perceptions may differ though. Some prefer monetary appraisals while some shows more attraction if provided with non-monetary benefits including promotions and more working empowerment. 


\section{Review of Economics and Development Studies, Vol. 6 (3) 2020, 6o7-624}

From Table 6, the negative perception regarding appraisals can be seen. The feedback from the second category of Likert Scale apparently reveals that the average number of universities operating in $\mathrm{KP}$ is not efficient enough with their employee compensation plans. The impact can be observed by job satisfaction and employee's turnover criterion. Item number 4 though indicates an exception with percentage yield of 36.0 and shows positive perception as it is within the fourth category of Likert Scale. The maximum percentage is the proof that evaluation is thoroughly done in all the institutes of KPS. Surprisingly the second highest figure 32.8 with items 2 and 5 indicates negative perception and lies in the second category of Likert Scale. This percentage asserts the investigated institutions seem productive in their response and appraisals given to the lecturers. The percentages 32.0 and 30.5 are in particular for items 1 and 3 which again assert lacking in reward and promotion systems. Hence the aggregate MAS relative to the figure 2.7964 confirm the absence of proactive appraisal systems based on merit and concrete performance. Conclusively, in order to attain reduction in turnover and to enhance teacher's output it is mandatory to remunerate them according to their skills and performance.

Table 6: Distribution of respondents with respect to performance appraisal

\begin{tabular}{|c|c|c|c|c|c|c|c|}
\hline \multirow[t]{2}{*}{ S.NO } & \multirow[t]{2}{*}{ Item } & \multicolumn{5}{|c|}{ Employee Perception } & \multirow[t]{2}{*}{ MAS } \\
\hline & & 1. & 2. & 3. & 4. & 5 . & \\
\hline 1 & $\begin{array}{l}\text { Your university } \\
\text { provides planned } \\
\text { returns to you. }\end{array}$ & $\begin{array}{l}27 \\
(21.6)\end{array}$ & $\begin{array}{l}40 \\
(32.0)\end{array}$ & $\begin{array}{l}25 \\
(20.0)\end{array}$ & $\begin{array}{l}28 \\
(22.4)\end{array}$ & $\begin{array}{l}5 \\
(4 \cdot 0)\end{array}$ & 2.5520 \\
\hline 2 & $\begin{array}{l}\text { The management } \\
\text { uplifts you on } \\
\text { achieving the set } \\
\text { targets and rewards } \\
\text { you accordingly. }\end{array}$ & $\begin{array}{l}21 \\
(16.8)\end{array}$ & $\begin{array}{l}41 \\
(32.8)\end{array}$ & $\begin{array}{l}28 \\
(22.4)\end{array}$ & $\begin{array}{l}31 \\
(24.8)\end{array}$ & $\begin{array}{l}4 \\
(3.2)\end{array}$ & 2.6460 \\
\hline 3 & $\begin{array}{l}\text { Promotions are given } \\
\text { on pure merit. }\end{array}$ & $\begin{array}{l}20 \\
(16.0)\end{array}$ & $\begin{array}{l}38 \\
(30.4)\end{array}$ & $\begin{array}{l}30 \\
(24.0)\end{array}$ & $\begin{array}{l}30 \\
(24.0)\end{array}$ & $\begin{array}{l}7 \\
(5.6)\end{array}$ & 2.7280 \\
\hline 4 & $\begin{array}{l}\text { Performance } \\
\text { evaluation is the } \\
\text { regular part of the } \\
\text { process. }\end{array}$ & $\begin{array}{l}9 \\
(7 \cdot 2)\end{array}$ & $\begin{array}{l}17 \\
(13.6)\end{array}$ & $\begin{array}{l}33 \\
(26.4)\end{array}$ & $\begin{array}{l}45 \\
(36.0)\end{array}$ & $\begin{array}{l}21 \\
(16.8)\end{array}$ & $3 \cdot 4160$ \\
\hline 5 & $\begin{array}{l}\text { Lecturers are given } \\
\text { appraisals according to } \\
\text { their output. }\end{array}$ & $\begin{array}{l}27 \\
(21.6)\end{array}$ & $\begin{array}{l}41 \\
(32.8)\end{array}$ & $\begin{array}{l}21 \\
(16.8)\end{array}$ & $\begin{array}{l}22 \\
(17.6)\end{array}$ & $\begin{array}{l}14 \\
(11.2)\end{array}$ & 2.6400 \\
\hline & Aggregate Mean & & & & & & 2.7964 \\
\hline
\end{tabular}

$1=$ strongly Disagree, $2=$ Disagree, $3=$ neutral, $4=$ Agree, $5=$ strongly Agree; MAS $=$ mean average score

\subsubsection{With respect to job satisfaction:}

Job satisfaction plays a crucial role in employee's satisfaction, productivity and employees turnover. A worker satisfied with his/her working conditions, satisfied with the received financial/nonfinancial appraisals and the overall response of an organization towards his/her work will impact strongly on the outcome of an organization. 
Review of Economics and Development Studies, Vol. 6 (3) 2020, 6o7-624

Table 7: Distribution of respondents with respect to job satisfaction

\begin{tabular}{|c|c|c|c|c|c|c|c|}
\hline \multirow[t]{2}{*}{ S.NO } & \multirow[t]{2}{*}{ Item } & \multicolumn{5}{|c|}{ Employee Perception } & \multirow[t]{2}{*}{ MAS } \\
\hline & & 1. & 2. & 3. & 4. & 5. & \\
\hline 1 & $\begin{array}{l}\text { You are contented with } \\
\text { your work at your } \\
\text { workplace. }\end{array}$ & $\begin{array}{l}6 \\
(4.8)\end{array}$ & $\begin{array}{l}20 \\
(16.0)\end{array}$ & $\begin{array}{l}22 \\
(17 \cdot 6)\end{array}$ & $\begin{array}{l}58 \\
(46.4)\end{array}$ & $\begin{array}{l}19 \\
(15 \cdot 2)\end{array}$ & 3.5120 \\
\hline 2 & $\begin{array}{l}\text { You are contented with } \\
\text { your Management. }\end{array}$ & $\begin{array}{l}14 \\
(11.2)\end{array}$ & $\begin{array}{l}35 \\
(28.0) \\
\end{array}$ & $\begin{array}{l}25 \\
(20.0) \\
\end{array}$ & $\begin{array}{l}40 \\
(32.0) \\
\end{array}$ & $\begin{array}{l}11 \\
(8.8) \\
\end{array}$ & 2.9920 \\
\hline 3 & $\begin{array}{l}\text { You are contented with } \\
\text { your affiliation with } \\
\text { your subordinates at } \\
\text { your workplace. }\end{array}$ & $\begin{array}{l}4 \\
(3.2)\end{array}$ & $\begin{array}{l}6 \\
(4.8)\end{array}$ & $\begin{array}{l}12 \\
(9 \cdot 6)\end{array}$ & $\begin{array}{l}69 \\
(55.2)\end{array}$ & $\begin{array}{l}34 \\
(27.2)\end{array}$ & 3.9840 \\
\hline 4 & $\begin{array}{l}\text { You are contented with } \\
\text { your remuneration at } \\
\text { University. }\end{array}$ & $\begin{array}{l}21 \\
(16.8)\end{array}$ & $\begin{array}{l}34 \\
(27.2)\end{array}$ & $\begin{array}{l}26 \\
(20.8)\end{array}$ & $\begin{array}{l}34 \\
(27.2)\end{array}$ & $\begin{array}{l}10 \\
(8.0)\end{array}$ & 2.8240 \\
\hline 5 & $\begin{array}{l}\text { You are contented with } \\
\text { the available career } \\
\text { development } \\
\text { opportunities at your } \\
\text { workplace. }\end{array}$ & $\begin{array}{l}20 \\
(16.0)\end{array}$ & $\begin{array}{l}48 \\
(38.4)\end{array}$ & $\begin{array}{l}17 \\
(13.6)\end{array}$ & $\begin{array}{l}34 \\
(27.2)\end{array}$ & $\begin{array}{l}6 \\
(4.8)\end{array}$ & 2.6640 \\
\hline 6 & $\begin{array}{l}\text { All-inclusive there is } \\
\text { contentment on your } \\
\text { part at University. }\end{array}$ & $\begin{array}{l}15 \\
(12.0)\end{array}$ & $\begin{array}{l}24 \\
(19.2)\end{array}$ & $\begin{array}{l}28 \\
(22.4)\end{array}$ & $\begin{array}{l}46 \\
(36.8)\end{array}$ & $\begin{array}{l}12 \\
(9.6)\end{array}$ & 3.1280 \\
\hline & Aggregate Mean & & & & & & 3.1840 \\
\hline
\end{tabular}

$1=$ strongly Disagree, $2=$ Disagree, $3=$ neutral, $4=$ Agree, $5=$ strongly Agree; MAS = mean average score

Table 7 demonstrates the affirmative feedback of respondents in accordance of their job contentment. The maximum percentage $(55.2 \%)$ is observed for third number item which is visible in Likert scale's fourth category, this elaborates that the relational aspect of an employee towards other subordinates is satisfactory. 46.4 is the second highest percentage observed which is for number 1 item, visible in the Likert scale's fourth category that indicates that majority of respondents are actually contented with their organization.

The aggregate MAS (3.18) depicts a positive feedback of workers which shows that they are happy with their working environment and the reimbursements. Other relevant queries including interpersonal relations, overall contentment and work opportunities also reflected the efficiency of management towards their goals. Hence, if dealt with consistency and wisdom, the motive of increased satisfaction and reduced turnover can be successfully attained.

\subsection{4 with respect of turnover:}

Turnover also plays an important role in organization's overall success and productivity. A firm showing rising trend towards turnover reflects inefficient HR practices. Table 8 demonstrates the concept with respect of the study taken into account. 
Review of Economics and Development Studies, Vol. 6 (3) 2020, 6o7-624

Table 8: Distribution of respondents with respect to turnover

\begin{tabular}{|c|c|c|c|c|c|c|c|}
\hline \multirow[t]{2}{*}{ S.No } & \multirow[t]{2}{*}{ Item } & \multicolumn{5}{|c|}{ Employee Perception } & \multirow[t]{2}{*}{ MAS } \\
\hline & & 1. & 2. & 3. & 4. & 5. & \\
\hline 1. & $\begin{array}{l}\text { You often consider } \\
\text { leaving current job. }\end{array}$ & $\begin{array}{l}8 . \\
(6.5)\end{array}$ & $\begin{array}{l}31 . \\
(24 \cdot 9) \\
\end{array}$ & $\begin{array}{l}31 . \\
(24.9) \\
\end{array}$ & $\begin{array}{l}32 . \\
(25 \cdot 7 .) \\
\end{array}$ & $\begin{array}{l}23 . \\
(18.5) \\
\end{array}$ & 3.2481 \\
\hline 2. & $\begin{array}{l}\text { Next year you will join } \\
\text { some other place to } \\
\text { work. }\end{array}$ & $\begin{array}{l}9 \\
(7.2)\end{array}$ & $\begin{array}{l}19 \\
(15 \cdot 2)\end{array}$ & $\begin{array}{l}26 \\
(20.8)\end{array}$ & $\begin{array}{l}45 \\
(36.0)\end{array}$ & $\begin{array}{l}26 \\
(20.8)\end{array}$ & 3.4800 \\
\hline 3. & $\begin{array}{l}\text { Recently, you are } \\
\text { interested in various job } \\
\text { offers in newspapers. }\end{array}$ & $\begin{array}{l}11 \\
(8.8)\end{array}$ & $\begin{array}{l}20 \\
(16.0)\end{array}$ & $\begin{array}{l}20 \\
(16.0)\end{array}$ & $\begin{array}{l}39 \\
(31.2)\end{array}$ & $\begin{array}{l}35 \\
(28.0)\end{array}$ & 3.5360 \\
\hline & Aggregate Mean & & & & & & 3.4214 \\
\hline
\end{tabular}

$1=$ strongly Disagree, $2=$ Disagree, $3=$ neutral, $4=$ Agree, $5=$ strongly Agree; MAS $=$ mean average score

Table 8 again demonstrates positive feedback of respondents with respect to the turnover. The maximum percentage can be seen for item number 2 which is 36.0\% and visible in Likert scale's fourth category, indicates that workers are looking for new opportunities around them. The second highest percentage seen so far is 31.2\% representing item number 3 and lies in the fourth category of Likert scale indicating that workers are referring to the newspapers to search the new opportunities. 25.6\% represents item number 1 and can be seen in the fourth category of Likert scale indicating the increased willingness of employees to change their workplace. In general the analysis depicts the positive perception and intention of employees to leave/change their current jobs with MAS of 3.421.

The aggregate MAS of turnover though illustrated the positive feedback, but the negativity in responses indicates that instructors would love to change their jobs if they get a chance. The organizations thus need to revise their HR policies which are influencing their employees to get motivated towards other more attractive offerings. In short if universities make sure to take an initiative of improvement and tries to retain their teachers with more rewards/promotions, , there would be fewer chances that instructors will change their workplaces.

\subsubsection{Overall MASS of variables:}

Table 9 demonstrates aggregate MAS of HR practices including employee participation, training and induction and appraisal system along with employee turnover and job satisfaction. As mentioned above, some of the asked queries were replied negatively.

MAS reflecting these queries thus represents the 'strongly agree' or 'strongly disagree' approaches of employees. The overall MAS as can be seen are slightly below 3. The overall perception of respondents was quite satisfactory except for two variables i.e. Performance appraisal systems and training and induction.

Table 9: MAS of variables

\begin{tabular}{|l|l|}
\hline Attributes. & Mean Average Score (MAS) \\
\hline Worker's contribution. & 3.0754 \\
\hline Training \& Induction. & 2.3153 \\
\hline Performance appraisal system. & 2.7965 \\
\hline Work contentment. & 3.1841 \\
\hline Turnover. & 3.4214 \\
\hline
\end{tabular}




\section{Regression Results and Discussion}

The software of regression analysis SPSS v. 20 was used for assessment of causal regression between dependent and independent variables. In particular, the influences of HR practices such as employee contribution, job contentment and turnover were thoroughly analyzed. It is perceptible as data investigated was largely cross sectional in nature therefore the value of coefficient is anticipated to come low. Due to this reason the basic dependency is on f-value, and p-value.

\section{Table 10. Regression Analysis between Dependent and Independent Variables}

\begin{tabular}{|l|l|l|l|l|l|l|l|l|}
\hline Ind. Variables & \multicolumn{4}{|l|}{ Dependent Variables } \\
\hline & \multicolumn{4}{|l|}{ Job satisfaction } & \multicolumn{2}{l|}{ Turnover intention } \\
\hline & $\beta$ & $\mathrm{R}^{2}$ & $\Delta \mathrm{R}^{2}$ & $\mathrm{~F}$ & $\beta$ & $\mathrm{R}^{2}$ & $\Delta \mathrm{R}^{2}$ & $\mathrm{~F}$ \\
\hline Emp. contribution & $.713^{* * *}$ & $.507^{* *}$ & .407 & $49.56^{*}$ & $-.422^{* *}$ & $.178^{* *}$ & .124 & $6.33^{* *}$ \\
\hline Training \& C. dev. & $.553^{* *}$ & $.305^{* *}$ & .417 & $54.04^{* * *}$ & $-.219^{* *}$ & $.048^{* *}$ & .033 & $6.168^{*}$ \\
\hline Per. Appraisal system & $.679^{* *}$ & $.461^{*}$ & .382 & $104.9^{* *}$ & $-.412^{* *}$ & $.168^{*}$ & .094 & $24.9^{*}$ \\
\hline
\end{tabular}

${ }^{*} \mathrm{p}<.05$

${ }^{* *} \mathrm{p}<.01$

$* * * \mathrm{p}<.001$

Table 10 shows regression analysis for the effects of employee contribution, training \& development, and performance appraisal system upon Job satisfaction and Turnover intention. Hypotheses were tested by employing standard multiple regression using SPSS version 20. This research did not take demographics as control variables in our study as they have not proven to substantially affect the selected dependent variables. The regression measures the degree of variation in dependent variable brought about by independent variable.

The result for the first independent variable i.e. employee contribution shows that the $\beta$ value for Jobs satisfaction is .713 while the total variance in job satisfaction explained by employee contribution is $50 \%, F(4,125)=49.56$. On the other hand, employee contribution showed an inverse relation with job turnover. In this case, the $\beta$ value is -.422 while the total variance in Turnover intention explained by employee contribution is $17 \%, F(4,125)=26.42$. These calculations provide sufficient evidence regarding employee contribution that has significant negative causation toward turnover. This implies that if workers are empowered to contribute in university affair they will be more satisfied and would least look at other options such as to quit.. In other words, lesser employee participation will encourage employees to quit their jobs and turnover ratio might increase drastically.

This evaluation clearly illustrates that the employee participation is a key contributor in enhancement of workers satisfaction. Contribution of workers increases workers motivation and faithfulness, which ultimately influences organization to achieve its goals successfully (khan et al., 2012). In similar vein, Scott, Bishop and Chen (2003) also assert that work satisfaction plays the role of intermediary between the ingredients of contributory and conducive working environment and worker's initiative to work professionally with other colleagues.

The second set of independent variable i.e. Training \& career development shows that the $\beta$ value for Jobs satisfaction is .553 while the total variance in job satisfaction explained by employee contribution is $30 \%, F(4,125)=54.04$. The affiliation between employee's satisfaction and training 


\section{Review of Economics and Development Studies, Vol. 6 (3) 2020, 607-624}

were discussed several times in previous researches too. Bradley, Petrescu and Simmons (2004) assert that training and induction has quite significant influences on overall HR practices. Their investigation also reveals that training enhances working abilities of an individual that ultimately affect the overall productivity of an organization.

Similarly, our analysis finds an inverse relation of Training \& development with Turnover intention. The $\beta$ value is -.219 while the total variance in Turnover intetnion explained by employee contribution is $4 \%, F(4,125)=6.16$. The $\mathrm{R}$ - square for turnover is 0.48 that indicates a very less training impact on turnover intention. The inferences drawn thus depict that if provided with progressive career development options and trainings, employees will intent less to leave their current jobs. In a similar vein, Batt and Valcour (2003) investigated that high-participative practices including collaboration, anatomy and training and inductions would lead to less turnover and increased output.

The third independent variable is Performance appraisal system. Table 10 shows that the $\beta$ value for Jobs satisfaction is .679 while the total variance in job satisfaction explained by employee contribution is $46 \%, F(4,125)=104.9$. This high yield of percentage depicts that if workers are provided with a rigorous appraisal system, they will be expected to display greater motivation and job satisfaction levels. This finding is in line with contemporary research where for instance, Karimi et al. (2011) examined affiliation of worker's performance appraisal with satisfaction of employees and found a positive affiliation between the two.

Lastly, Performance appraisal system shows an inverse relation with that of Turnover intention. The corresponding figure shows that the $\beta$ value for Turnover intention is -.412 while the total variance in Turnover intention explained by employee contribution is $16 \%, F(4,125)=24.9$. From the above interpreted calculations, sufficient base is allocated to performance appraisal directing employee turnover that is negative and significant. The calculated R- square is 0.168 which shows that there is around $17 \%$ change brought about by appraisal system in employee's turnover. This result infers that a stronger appraisal system will tend to lower the turnover rates among University employees. It should be noted here that these findings are based on presumption of fair, nepotism-free appraisal system which is expected to enhance employee's productivity and overall satisfaction.

\section{Implications, Limitations and Conclusion}

In line with previous research on job satisfaction, this research too finds existence of significant relationship between employees' job satisfaction and employee turnover with that of several HRM practices. Nevertheless, this relationship is found in a unique context of KP where a number of factors such as terrorism, disasters, and deadly diseases have worsened security conditions thus exacerbating employees' satisfaction among universities in general. The results revealed that an average of $70 \%$ increase in job satisfaction and turnover is brought about by selected HR strategies like employee contribution, skill refinement, and performance appraisement system. This on the other hand confirmed the dependability of the data collection. The conclusion drawn after the statistical analysis of facts and figures is that there is an affirmative strong relation between HR strategies and contentment of employees in Pakistan (Ahmed et al., 2017) yet an adverse effect of HR strategies was found over the financial yield of professors of private and public sector universities of Peshawar and neighbouring cities.

The results reveal that the professors of Universities of KP are passionate and enthusiastic to contribute in the university at their level best. They would only be able to contribute strongly if the prevalent HR practices are favourable and employee-friendly. Nevertheless in practice, most 


\section{Review of Economics and Development Studies, Vol. 6 (3) 2020, 6o7-624}

universities fail to provide proper skills refinement, opportunities and performance appraisal system to the teaching community. This kind of misconduct from the university side is bearing a negative impact on contentment of their employees and consequently, they are being pushed towards quitting the jobs or alternate job opportunities. It is observed that several foreign qualified professors of universities in KP have tried to move to national institutions in Islamabad, Lahore and Karachi. In order to achieve optimum performance, universities must adopt specific HR strategies adequately and competently. It is also concluded from the figures that to make your employees contended and devoted towards universities, performance appraisal and HR strategies (such as employee contribution and employee training) must be applied efficiently and effectively.

The current research therefore bears widespread implications for HR strategies and policies in a special and troublesome context of higher educational institutions of KP. First, the KP universities should make best possible use of HRM strategies and policies in order to derive maximum performance and retain employee turnover. Second, the stakeholders should focus on enhancing job satisfaction and reducing turnover to combat the negative perceptions in prevailing situations of terrorism and chaos in KP. It has been observed that faculty members in KP and Pakistan in general try to settle in any possible foreign universities in middle-east, Europe and North-America in an escape from terrorism and insecurity. This research offers a viable strategy, amongst many other effective ones to overcome the problem of brain-drain from important academic positions in the region. Third, the theoretical association of HR practices and job outcomes has shown diverging results to those of prior research.

Finally, this study has had several limitations too which are to be overcome by future researchers. For instance, the sample size needs to be increased manifold so that wider generalizations can be offered. It will be better to include non-teaching staff to examine their levels of satisfaction and turnover. Other important variables relating to HR practices might need be incorporated in future. Finally, future research may also consider comparing the results across other cities of Pakistan and international borders.

\section{REFERENCES}

Abassi, SM \& Hollman, KW. (2000). Turnover: the real bottom line, Public Personnel Management, 2 (3), 333-42.

Abeysekera R. (2007). The impact of human resource management practices on marketing executive turnover of leasing companies in Srilanka. A contemporary management research, 3 (3), 233252.

Agho, A. O., Price, J. L., \& Mueller, C. W. (1992). Discriminant validity of measures of job satisfaction, positive affectivity and negative affectivity. Journal of Occupational and Organizational Psychology, 65(3), 185-195.

Absar M. M. N., Azim M. T., Balasundaram N., Akhter S. (2010). Impact of human resource practices on job satisfaction: evidence from manufacturing firms in Bangladesh, Economic science series, LXII (2), 31-42.

Ahmed, A., Zaman, Y., \& Khattak, A. (2017). Impact of HR practices on employee's job satisfaction: A case study from fertilizer industry of Pakistan. Management Science Letters, 7(5), 225-232.

Akerlof, G. A. (1984). Gift exchange and efficiency-wage theory: Four views. The American Economic Review, 74(2), 79-83.

Allen D. G., Shore L.M., Griffeth R.W. (2003). The role of perceived organizational support and supportive human resource practices in the turnover process. Journal of Management, 29 (1), 99-118.

Arumugam.V.C. \& Mojtahedzadeh.R. (2011). The Impact of HRM practices on financial performance of 


\section{Review of Economics and Development Studies, Vol. 6 (3) 2020, 6o7-624}

Malaysian industries. International Research Journal of Finance and Economics, 80, 49-54.

Aswathappa, K. (2008). Human Resource Management: Text and Cases, Tata McGraw-Hill Publishing Company Limited, Delhi.

Bame. (1993). Organizational characteristics and administrative strategies associated with staff turnover, Health Care Management Review, 18 (4), 70-86.

Batt R. and Valcour P. M. (2003). Human resource practices as predictors of work-family outcomes and employee turnover. Industrial relations: journal of economy and society, 42, 182-220.

Belzen M. V. (2009). The relation between bundled HR practices and employee job satisfaction in the Dutch pharmacy sector. School of business and economics.

Blaug, M. (1976). The empirical status of human capital theory: A slightly jaundiced survey. Journal of economic literature, 14(3), 827-855.

Bradley, S., Petrescu, A., \& Simmons, R. (2004, May). The impacts of human resource management practices and pay inequality on workers' job satisfaction. In Western Economic Association 79th Annual Conference Vancouve.

Brown, M., \& Heywood, J. S. (2005). Performance appraisal systems: determinants and change. British Journal of Industrial Relations, 43(4), 659-679.

Dalton, D. \& Todor, WD. (1981). Turnover, Transfer, Absenteeism: An Interdependent Perspective, Journal of Management, 19 (2), 193-220.

DeMicco FJ \& Giridharan, J. (1987). Managing employee turnover in the hospitality industry, FIU Hospitality Review, pp. 26-32.

Dyke, TV \& Strick, S. (1990). Recruitment, selection and retention of managers in the hotel and restaurant industry', FIU Hospitality Review, pp. 1-9.

Delaney J. T. and Huselid M. A. (1996). The impact of human resource management practices on perceptions of organizational performance. The academy of management journal, 39 (4), 949969.

Gary, D. (2008). A Framework for Human Resource Management. Pearson Education India.

Griffin, M., \& Griffin, W. (2001). Organizational Behavior People and Organization, sixth Edition Arizona state University. Managing Houghton Mifflin Company, Boston New York, 220-246.

Gurbuz S. (2009). The effect of high performance HR practices on employee's job satisfaction. Istanbul university journal of the school of business administration, 38 (2), 110-123.

Hussain, T., \& Rehman, S. S. (2013). Do Human Resource Management Practices Inspire Employees' Retention? Research Journal of Applied Sciences, Engineering and Technology, 6 (19), 36253633 .

Huselid M. A. (1995). The impact of human resource management practices on turnover, productivity, and corporate financial performance. The academy of management journal, 38 (3), 635-672.

Karimi, R., Malik, M. I., \& Hussain, S. (2011). Examining the relationship of performance appraisal system and employee satisfaction. International Journal of Business and Social Science, 2(22).

Khan, A. H., Nawaz, M. M., Aleem, M., \& Hamed, W. (2012). Impact of job satisfaction on employee performance: An empirical study of autonomous Medical Institutions of Pakistan. African Journal of Business Management, 6(7), 2697.

Kevin, MM, Joan, LC \& Adrian, JW. (2004). Organizational change and employee turnover, Personnel Review, 33 (2), 161-166.

Koys. D.J. (2001). Effects of Employees satisfaction, Organizational citizenship behaviour and Turn over on Organizational effectiveness: Unit level longitudinal study. Personnel Psychology, 54, 101-114.

Kundu, S. C., \& Gahlawat, N. (2015). Socially responsible HR practices and employees' intention to quit: The mediating role of job satisfaction. Human Resource Development International, 18(4), 387406.

Lee, F H and Lee, F Z. (2007). The relationships between HRM practices, leadership Style, competitive 


\section{Review of Economics and Development Studies, Vol. 6 (3) 2020, 6o7-624}

strategy and Business performance in Taiwanese steel industry, Proceedings of the 13th Asia pacific management conference, Melbourne, Australia, 953-971.

Ma, S., Silva, M. G., Callan, V. J., \& Trigo, V. (2016). Control and commitment HR practices, job satisfaction and turnover intentions: a comparison between local and multinational firms in China. The International Journal of Human Resource Management, 27(9), 974-990.

Meaghan, S \& Nick, B. (2002). Voluntary turnover: knowledge management-friend or foe?, Journal of intellectual capacity, 3 (3), 303-322.

Mahmud K. and Idrish S. (2011). The impact human resource management practices on turnover of bank employees in Bangladesh. World review of business research, 1(2), 71-83.

Mobley, W. H., Horner, S. O., \& Hollingsworth, A. T. (1978). An evaluation of precursors of hospital employee turnover. Journal of Applied psychology, 63(4), 408.

Mumtaz A., Khan I., Aslam H. D., Ahmad B. (2011). Impact of the HR practices on job satisfaction of university teachers: evidence from university in Pakistan. Industrial engineering letters, 1 (3)

Mudor H., Tooksoon P. (2011). Conceptual framework on the relationship between human resource management practices, job satisfaction and turnover. Journal of economics and behavioral studies, 2 (2), 41-49.

Martin M. J. (2011). Influence of human resource practices on employee intention to quit.

Nishi L. H., Lepak D. P., Schneider B. (2008). Employee attributions of the "why" of HR practices: Their effects on employee attitudes \& behaviors, and customer satisfaction. Personnel psychology, 61, 503-545.

Olusegun, S. O. (2013). Influence of job satisfaction on turnover intentions of library personnel in Selected Universities in South West Nigeria.

Rathanweera, R. R. (2010). Do HRM practices impact employee's satisfaction, commitment or Retention? (Empirical Studies of Sri Lankan public sector Banks). Published Master's Thesis, University of Agder.

Roberto Luna-Arocus, Jaoquin Camps. (2007). A model of high performance work practices and turn over intentions. Personnel review, 37 (1), 26-46.

Rogg K. L., Schmidt D. B., Shull C., Schmitt N. (2001). Human resource practices, organizational climate and customer satisfaction. Journal of management, 27(4), 431-449.

Scott, D., Bishop, J. W., \& Chen, X. (2003). An examination of the relationship of employee involvement with job satisfaction, employee cooperation, and intention to quit in US invested enterprise in China. The International Journal of Organizational Analysis, 11(1), 3-19.

Stavrou Costea, E. (2005). The challenges of HRM towards organizational effectiveness. Journal of European industrial training, 29 (2), 112-134

Shahzad K., Bashir S., Ramay M. I. (2008). Impact of HR practices on perceived performance of university teachers in Pakistan. International review of business research papers, 4 (2), 302-315.

Shaffer, M. A., Harrison, D. A., \& Gilley, K. M. (1999). Dimensions, determinants, and differences in the expatriate adjustment process. Journal of International Business Studies, 557-581.

Trevor C. O. and Nyberg A. J. (2008). Keeping your head count when all about you are losing theirs: downsizing, voluntary rates, and the moderating role of $\mathrm{HR}$ practices. The academy of management journal, 51(2), 259-276.

Week, B. (2000). Knowledge management and new organization forms: a framework for business model innovation. Knowledge management and virtual organizations, 2-19.

Wright P.M., Gardner T. M., Moynihan L. M. (2003). The impact of HR practices on the performance of business units. Human resource management journal, 13 (3), 21-36.

Zaini A., Nilufar A. and Syed S. A. (2009). The effects of HRM practices on business performance among private companies in Malaysia. International journal of business and management, 4 (6), 65-72. 